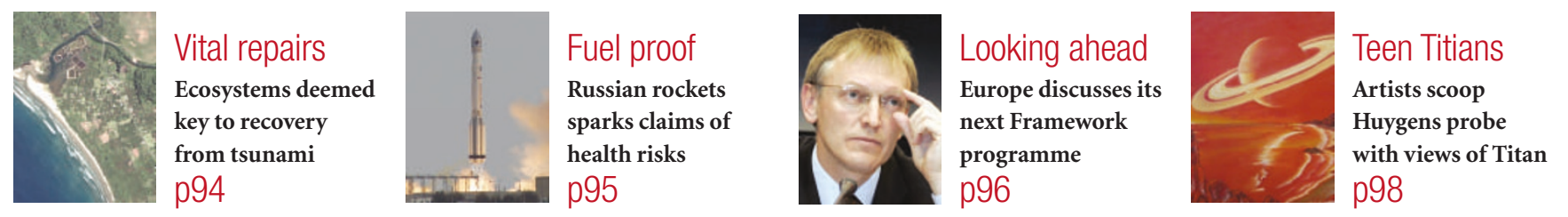

\title{
Forces gather behind proposal for a natural-disaster agency
}

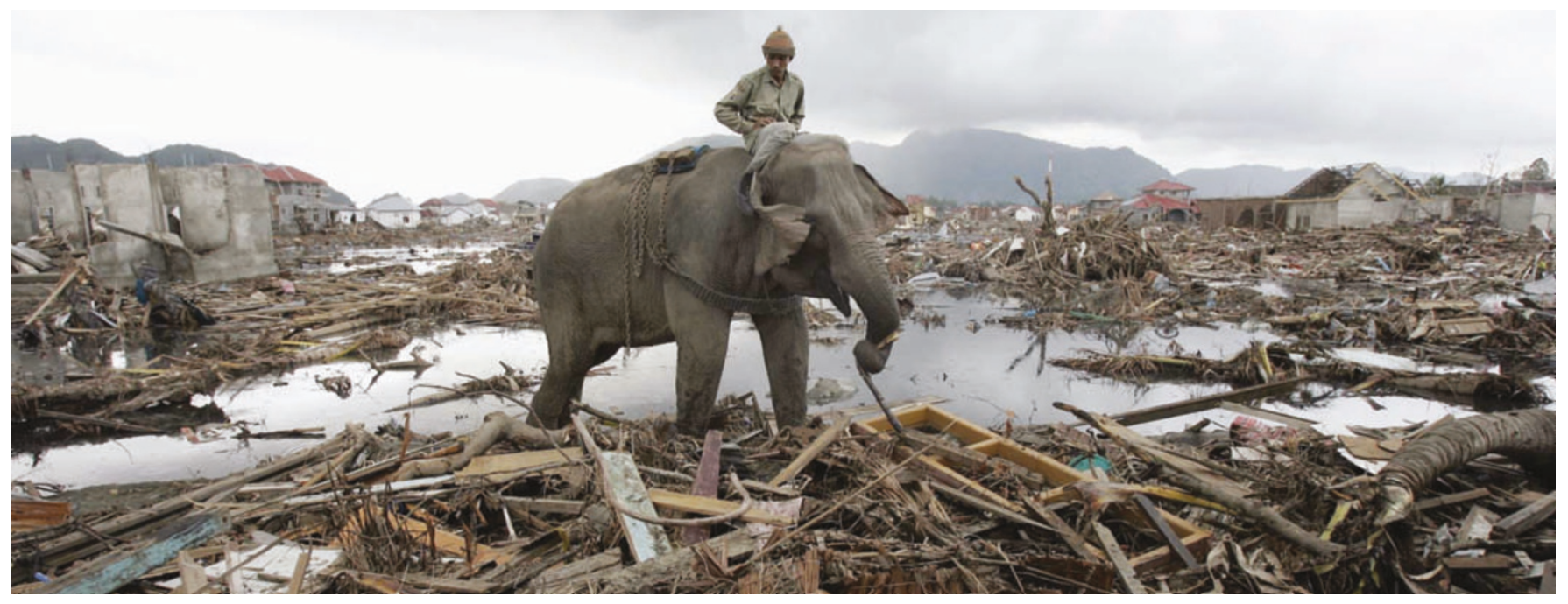

As relief workers survey the wreckage from the Asian tsunami, international pressure is being channelled into moves to anticipate such crises.

Jim Giles, London and Emma Marris, Washington Following the recent tsunami in the Indian Ocean, momentum is building behind a plan for an international body that would coordinate preparations for natural disasters.

David King, the UK government's chief scientific adviser, is actively pushing for such a body. He says the idea will be promoted by UK officials at meetings of the G8 - the world's eight largest industrialized countries - which will take place in Britain this year. "With world attention focused on natural disasters, it's an idea that many people feel is ripe," says King.

Academics who were contacted by Nature had varying ideas about how such a panel should function, but gave the thrust of the proposal almost unanimous support. "This needs to be put together now," says Robert Watson, chief scientist at the World Bank in Washington DC.

Although the proposal is still in its infancy, King has put some thought into how it should work. He suggests that a permanent group of natural and social scientists, together with economists, should periodically review research into natural disasters, in much the same way that the Intergovernmental Panel on Climate Change (IPCC) looks at research on global warming. Their findings would be channelled into recommendations for risk- reduction schemes, warning systems and future research priorities, he says. The body could complement an international disasterrelief organization, calls for which are also attracting political attention.

"There are a large number of bodies already doing this. We need to pull things together under a single umbrella," says King.

\section{Existing foundations}

The organization currently performing the role closest to that proposed by King is the United Nations International Strategy for Disaster Reduction (ISDR), based in Geneva, Switzerland. This agency has an annual budget of just US\$5 million and is currently restricted to promoting governments' awareness of the need to prepare for natural disasters, from wildfires to storms and droughts.

Salvano Briceno, the agency's director, says it had been advocating a tsunami warning system for the Indian Ocean for several years, but lacked the political clout to implement it. Also in need of urgent attention, says Briceno, are building regulations in the earthquake-prone areas of less developed countries. When building codes are not enforced, the results can be catastrophic - as demonstrated by the earthquake in Bam, Iran, in December 2003, in which 30,000 people died.
A similar quake in California the same month killed only two people.

With extra funding and political backing, Briceno says, the ISDR could do the job that King is proposing. At the World Conference on Disaster Reduction, scheduled for 18-22 January in Kobe, Japan, Briceno plans to call on governments to channel a fraction of their humanitarian aid budgets into an enlarged ISDR, creating a fund worth hundreds of millions of dollars a year.

Despite broad support for a coordinating body, disagreement persists over how it should function. Some experts say that, like the IPCC, the panel should simply pass on assessments rather than making explicit recommendations and helping to implement them. "When scientific bodies tell governments what to do they get rejected," says Watson, a former chairman of the IPCC. It can be more effective to provide analyses and let governments take their own steps, he adds.

Others say the practicalities of handing out funds should be left to an organization such as the World Bank. It has the experience to ensure that scientific advice actually gets implemented, says Debarati Guha-Sapir, director of the Center for Research on the Epidemiology of Disasters in Brussels, Belgium. "And it has the financial muscle to get governments involved in projects." 